\title{
Research on Checking and Testing Method of Windproof Capability of Port Portal Crane
}

\author{
Yao-ting Tong ${ }^{1, *}$, Bo-zheng Wei ${ }^{2}$, Zheng-qiu Huang ${ }^{1}$, Li-xin Ren ${ }^{1}$ \\ ${ }^{1}$ Shanghai Institute of Special Equipment Inspection and Technical Research, Shanghai, 200062 \\ ${ }^{2}$ Shanghai Fengxian District Special Equipment Inspection Institute, Shanghai 201406
}

\begin{abstract}
In this paper, the effect of wind load on port portal crane is simulated by experimental method, and the anti-wind and anti-skid performance of port portal crane is tested. This experiment is an important method to study the action mode of wind force on port portal crane and the anti-wind and skid resistance of port portal crane, and provides an important basis for the evaluation of wind-proof safety performance of port portal crane.
\end{abstract}

\section{Introduction}

In order to test the windproof ability of the crane, it is necessary to determine the maximum wind load under the working state and non-working state of the crane, and then select the feasible experimental method in order to complete the wind-proof ability test and obtain the wind-proof safety performance. At present, the common test method is to simulate the effect of wind load on the crane by applying the force equal to the maximum wind load to the crane's traveling mechanism, obtain the relevant test data, and finally obtain the wind-proof ability of the windproof device ${ }^{[1]}$.

The common test methods are hydraulic cylinder double machine push simulation wind load mode, vehicle traction and manual hoist rope method simulation wind load and so on. Among them, manual hoist rope pulling method is suitable for some small cranes, and the suitable type is less, the operation is not convenient, and has certain limitations. The vehicle traction method cannot be synchronized in real time between two vehicles and the load size is not easy to control. Considering the operability, economy and safety of the on-site loading method, this method should not be adopted. Therefore, in order to load the synchronization, the portability of the equipment and the accuracy of the result data, this paper will adopt the double hydraulic rod push method to test the windproof performance of the equipment by simulating the wind load.

\section{Windproof ability check and test method}

\subsection{Windproof ability check calculation}

After the wind disaster, the main failure forms of portal crane are as follows: the whole crane slips, the crane overturns, and the metal structure of the crane destroys ${ }^{[2]}$. Among them, the sliding and overturning of the whole machine is more common, and the damage caused by the machine is the most serious. It is usually the most dangerous in the direction of the portal crane, that is, along the track direction of the portal crane, because the portal crane has the maximum upwind area (the boom direction is perpendicular to the direction of the wind load vector). In this test, the portal crane is selected perpendicular to the direction of the track (the direction of the maximum windward area); the wind force is selected as the 12 -level sudden strong wind $(35 \mathrm{~m} / \mathrm{s})$ in the working state and the storm $(55 \mathrm{~m} / \mathrm{s})$ in the nonworking state; the test device selects the brake ability of the portal crane brake and the windproof iron shoes under separate and combined working conditions to check whether the windproof ability of the windproof device meets the requirements. The experimental test principle of windproof safety device of crane should be based on the following formula:

$$
F_{\text {push }}<f_{\text {resis } \tan c e}
$$

Among them, $F_{\text {push }}$ is the thrust produced by wind load, $f_{\text {resistance }}$ is the friction force between crane wheel and track tread, and the tension produced by windproof device.

According to the requirements of the Ministry of Communications "regulations on the Prevention of Typhoon of large Machinery in Port" and the actual situation of the test site, the crane should ensure the ability to resist the 12 -level sudden gust $(35 \mathrm{~m} / \mathrm{s})$ under working condition and typhoon $(55 \mathrm{~m} / \mathrm{s})$ under nonworking condition. The wind load of the crane is calculated as follows:

Maximum working wind load:

$$
F_{I I}=C P_{I I} A
$$

Non-working wind loads:

$\overline{* \text { Corresponding author: tongyt } @ \text { ssei.cn }}$ 


$$
F_{I I I}=C K_{h} P_{I I I} A
$$

$\mathrm{F}_{\text {II- }}$ maximum wind load of crane in working state (N) ;

C-wind coefficient;

$\mathrm{P}_{\mathrm{II}}$-working state calculation of wind pressure $\left(\mathrm{N} / \mathrm{m}^{2}\right)$;

$\mathrm{F}_{\mathrm{III}}$ - maximum wind load of crane in working state (N) ;

$\mathrm{P}_{\mathrm{III}}$-non-working state calculation of wind pressure $\left(\mathrm{N} / \mathrm{m}^{2}\right)$;

A-the upwind area of the entity perpendicular to the wind direction of the lifting mechanism $\left(\mathrm{m}^{2}\right)$;

$\mathrm{K}_{\mathrm{h}}$-wind pressure height variation coefficient;

$\mathrm{V}$-wind speed $(\mathrm{m} / \mathrm{s})$.

According to the calculation results, the windproof capacity of the equipment can be checked.

\subsection{Wind proof capacity testing}

The anti-wind and anti-skid ability of the equipment can be calculated through theoretical check calculation and on-site testing ${ }^{[3]}$. Theoretical check calculation is to calculate each factor. If the formula 1 can be satisfied, the anti-wind and anti-skid ability of the equipment meets the requirements, otherwise it is not. The field test is to calculate the theoretical wind load of the crane, apply the equivalent force to the crane and simulate the wind load equivalently (try to apply the wind load application point to the crane traveling mechanism equivalently, so as to ensure that the wind proof test load of the crane can simulate the actual wind load more truly), and test the anti-wind and anti-skid ability of the equipment on site.

Taking the portal crane made by $32 \mathrm{~T}$ Shanghai Port Shipyard used in Waigaoqiao Shipyard as an example, according to the above formula, calculate the wind load of each component of the crane in working state 12-level sudden gusts and non-working state typhoon conditions. The calculation results are shown in the following table (the values of the wind coefficient, wind reduction coefficient, and wind pressure height change coefficient are selected in GB/T3811-2008 Table 16, Table 17, and Table 19 according to the actual situation of the component) ${ }^{[4]}$. As shown in Table 1, the wind load calculation results of the components of the equipment under the maximum non-working condition of the typhoon are as follows:

Table 1. Calculation results of wind load for each component

\begin{tabular}{|c|c|c|c|c|c|c|}
\hline Description & Area $\left(\mathrm{m}^{2}\right)$ & Angle $\left(^{\circ}\right)$ & $\begin{array}{l}\text { Wind } \\
\text { force } \\
\text { coefficient }\end{array}$ & $\begin{array}{l}\text { Windshield } \\
\text { reduction } \\
\text { coefficient }\end{array}$ & $\begin{array}{c}\text { Wind } \\
\text { pressure } \\
\text { height } \\
\text { variation } \\
\text { coefficient }\end{array}$ & $\begin{array}{c}\text { Non- } \\
\text { working } \\
\text { wind }(\mathrm{N})\end{array}$ \\
\hline Boom frame & 39.66 & 90 & 1.65 & 1 & 1.46 & 180632.09 \\
\hline $\begin{array}{l}\text { Lower end of } \\
\text { elephant nose } \\
\text { beam }\end{array}$ & 13.97 & 90 & 1.3 & 1 & 1.57 & 53906.96 \\
\hline $\begin{array}{l}\text { Upper end of } \\
\text { elephant nose } 1\end{array}$ & 6.07 & 90 & 1.7 & 1 & 1.62 & 31605.16 \\
\hline $\begin{array}{l}\text { Upper end of } \\
\text { elephant nose } 2\end{array}$ & 607 & 90 & 1.7 & 0.45 & 1.57 & 13783.36 \\
\hline Large pull rod & 10.64 & 90 & 1.9 & 1 & 1.57 & 60006.77 \\
\hline Balance beam 1 & 6.49 & 90 & 1.55 & 1 & 1.46 & 27767.36 \\
\hline Balance beam 2 & 6.49 & 90 & 1.55 & 0.3 & 1.46 & 8330.21 \\
\hline $\begin{array}{l}\text { Counterweight } \\
\text { after balancing } \\
\text { beam }\end{array}$ & 3.84 & 90 & 1.2 & 1 & 1.46 & 12719.52 \\
\hline $\begin{array}{l}\text { Left end of small } \\
\text { pull rod }\end{array}$ & 2.24 & 90 & 1.3 & 1 & 1.46 & 8038.03 \\
\hline $\begin{array}{l}\text { Right end of } \\
\text { small pull rod }\end{array}$ & 2.67 & 73.1 & 1.6 & 1 & 1.4 & 10351.65 \\
\hline Upward column 1 & 19.4 & 90 & 1.3 & 1 & 1.39 & 66277.37 \\
\hline Upward column 2 & 19.4 & 90 & 1.3 & 0.15 & 1.39 & 9941.61 \\
\hline Turntable 1 & 9.13 & 90 & 1.1 & 1 & 1.22 & 23164.81 \\
\hline Turntable 2 & 12.25 & 90 & 1.1 & 1 & 1.13 & 28788.07 \\
\hline Cylinder & 39.82 & 90 & 0.75 & 1 & 1 & 56463.52 \\
\hline Cross beam & 57.5 & 90 & 1.4 & 1 & 1 & 152195.31 \\
\hline End beam 1 & 2.38 & 90 & 1.1 & 1 & 1 & 4949.66 \\
\hline End beam 2 & 8.74 & 22.7 & 1.1 & 1 & 1 & 2706.75 \\
\hline mechanical room & 41.2 & 90 & 1.2 & 1 & 1.32 & 123383.70 \\
\hline Driver's room & 7.33 & 90 & 1.2 & 1 & 1.32 & 21951.52 \\
\hline $\begin{array}{l}\text { Caravan walking } \\
\text { mechanism }\end{array}$ & 0.721 & 90 & 1.1 & 1 & 1 & 1499.45 \\
\hline goods & 6.3196 & 90 & 1.7 & 1 & 1.46 & 0.00 \\
\hline
\end{tabular}


Through the calculation, it can be obtained that the wind force of the metal structure of the whole crane is about 89.85 t (about $898500 \mathrm{~N}$ ).

\subsubsection{Check calculation}

Taking the 32t portal crane manufactured by Shanghai Port Machinery Works in Waigaoqiao shipyard as an example, the whole machine has 32 wheels and 16 driving wheels. The crane traveling mechanism is divided into 4 groups, each group is equipped with 2 driving motors, 4 driving wheels and 4 driven wheels, each group of crane mechanism is equipped with 2 brakes and 4 iron shoes (iron shoes are placed forward and backward), and its anti-wind and anti-skid ability is obtained by the following ways: the brake of the equipment cart brakes the driving wheel, and the driving wheel generates sliding friction resistance to prevent the equipment from sliding; the driven wheel of the iron shoe plug pad promotes the driven wheel of the blocked pad from rolling operation to sliding operation, and the driven wheel generates sliding friction resistance to prevent the equipment from sliding; the rolling friction resistance generated by the rolling operation of the driven wheel prevents the equipment from sliding. Therefore, the anti-wind and anti-skid ability $F_{\text {ha }}$ of the equipment using iron shoes as windproof device is as follows:

$$
F_{h a}=F_{q} * N_{1}+F_{c h} * N_{c h}+F_{c g} * N_{c g}
$$

Among them, $\mathrm{F}_{\mathrm{q}}$ is the smaller value of braking force and sliding friction on a single active wheel, $F_{c h}$ is the anti-skid ability of a single follower behind the padded iron shoes, $F_{c g}$ is the anti-skid ability of the follower wheel of the unplugged iron shoes, $\mathrm{N}_{1}$ is the number of active wheels, $\mathrm{N}_{\mathrm{ch}}$ is the number of iron shoes, and $\mathrm{N}_{\mathrm{cg}}$ is the number of driven wheels for rolling.

For $\mathrm{F}_{\mathrm{q}}$, the sliding friction $\mathrm{F}_{2}$ is $23505.625 \mathrm{~N}$, which is smaller than the braking force $\mathrm{F}_{1}=25137 \mathrm{~N}$, so $\mathrm{F}_{\mathrm{q}}=13505.0625 \mathrm{~N}$.

With regard to $F_{c h}$, when the wind load blows along the track direction, the follower wheel acting on the iron shoes will also produce sliding friction force $F_{2}$, then $\mathrm{F}_{\mathrm{ch}}=\mathrm{F}_{2}=23505.0625 \mathrm{~N}$.

With regard to $F_{\mathrm{cg}}$, it is the anti-skid ability of the follower wheel of the unplugged iron shoes, that is, the rolling friction of the follower wheel, which is calculated by $\mathrm{F}_{\mathrm{cg}}=578.8125 \mathrm{~N}$.

When $\mathrm{N}_{1}=16, \mathrm{~N}_{\mathrm{ch}}=8, \mathrm{~N}_{\mathrm{cg}}=8, \mathrm{~F}_{\mathrm{ha}}$ can be calculated according to formula $1, \mathrm{~F}_{\mathrm{ha}}=837058.25 \mathrm{~N} \leq 898500 \mathrm{~N}$, the anti-wind and anti-skid ability of the equipment under non-working typhoon $(55 \mathrm{~m} / \mathrm{s})$ condition fails to pass the check. The equipment should be improved by adding anti wind and anti-skid devices (including brake, rail clamp, rail jacking device, windproof iron shoes, windproof cable and anchoring device).

\subsubsection{Field test of equipment's anti-wind and anti- skid ability}

It is highly feasible to use the hydraulic system to load the buffer device of the crane on both sides of the equipment to test the windproof ability (some ports choose two forklifts as the external power source to simulate the thrust generated by the wind load on the equipment for testing) [5], that is, to load the traveling device of the crane on both sides of the crane through the hydraulic cylinder to test its windproof and antiskid function. The schematic diagram of the test device is shown in Fig 1.

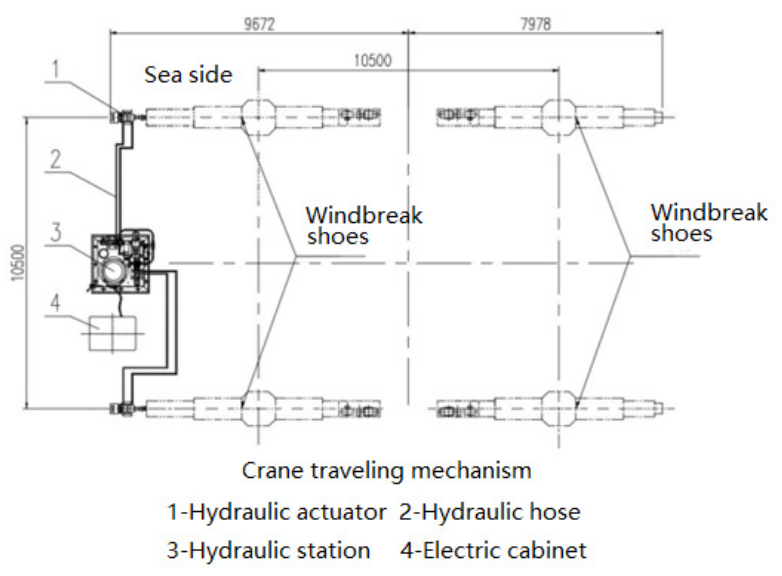

Fig 1. Layout of oil cylinder

The actuator as shown in Fig 2 is designed. The flow of the hydraulic cylinder is adjusted by the hydraulic control system, and the same load of theoretical wind load is applied to the crane to simulate the influence of wind load on the crane. The pressure sensor can be used to obtain the change law of the load on the cart with time. At the same time, the change of cart displacement can be obtained through the photoelectric sensor of the electrical system. By analyzing the changes of pressure sensor and photoelectric sensor at the same time, the windproof ability of crane windproof device can be known.

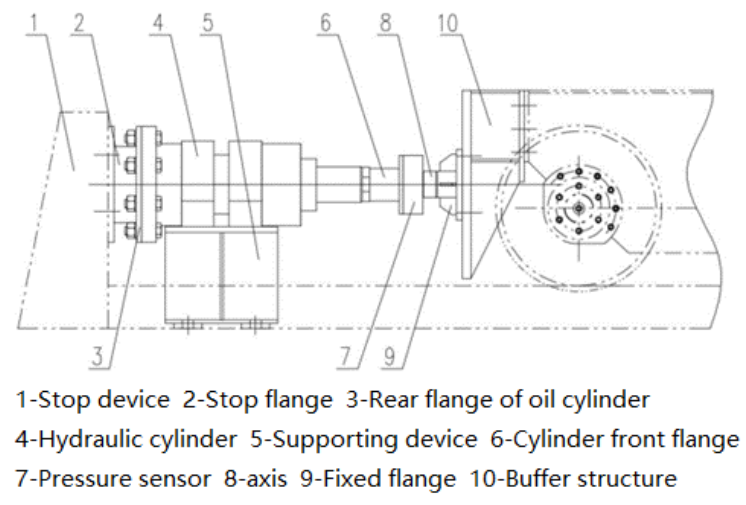

Fig 2. Schematic diagram of actuator

Load the above hydraulic devices on both sides of the hoisting machinery, and test the following items respectively: 
1) The crane boom is perpendicular to the track, the working brake works, and the windproof device (windproof iron shoes) does not work---test the windproof ability of the crane when it is not working.

2) The crane boom is perpendicular to the track, the working brake works, and the windproof device (windproof iron shoes) is working---test the windproof ability of the crane when it is not working.

3) The crane boom is parallel to the track, the working brake works, and the windproof device (windproof iron shoes) does not work---test the windproof ability of the crane when it is not working.

4) The crane boom is parallel to the track, the working brake works, and the windproof device (windproof iron shoes) is working---test the windproof ability of the crane when it is not working.

5) The crane boom is parallel to the track, the working brake does not work, and the windproof device (windproof iron shoes) is working---test the windproof ability of the crane when it is not working.

6) The crane boom is perpendicular to the track, the working brake does not work, and the windproof device (windproof iron shoes) is working ---test the windproof ability of the crane when it is not working.

After testing, the equipment in condition 6), and nonworking typhoon conditions, the equipment appeared slippage phenomenon, indicating that the equipment anti-wind and anti-skid ability is insufficient, verify the conclusion of the previous theoretical check chapter

\section{Conclusion}

In this paper, the effect of wind load on port portal crane is simulated by experimental method, and whether the port portal crane slips under the action of theoretical wind load is determined. If the crane slips before the theoretical wind load, it shows that the anti-wind antiskid device of the crane cannot meet the requirements of use, on the contrary, it shows that it meets the requirements. Continue to increase the horizontal thrust of the hydraulic cylinder until the ultimate load, if slip occurs before the ultimate load, then the corresponding wind load is the maximum windproof capacity of the crane. Through the calculation and analysis of the windproof capacity of the port portal crane, the windproof device can be set up reasonably to avoid the accident of the crane in the wind disaster.

\section{Acknowledgements}

First of all, I would like to express my sincere thanks to Shanghai Institute of Special Equipment Inspection and Technical Research. With the help of my colleagues, I completed this paper.

I am also deeply indebted to all the other tutors and teachers in Translation Studies for their direct and indirect help to me.

Special thanks should go to my friends who have put considerable time and effort into their comments on the draft.
Last my gratitude also extends to my family who have been assisting, supporting and caring for me all of my life.

\section{References}

1. Shi Yao. (2011) Research on the improvement and Test Technology of Wind proof ability of Portal Crane. Port loading and unloading, 06: 4-7.

2. Zhang Meizhong. (2009) Causes and prevention of overturning of large port cranes in strong winds, Port Science and Technology, 03:16-20.

3. Su Wensheng, Liang Youming, Bai Jianyi, et al. (2016) Development of wind proof performance test system for anti wind and anti slip device of crane. Lifting and transportation machinery, 11: 98-101.

4. GB/T 3811-2008. (2008) Code for Design of Crane.

5. Chen Mingqi, Zhu Jiankang, Ji Yucheng, et al. (2013) Design of anti wind and anti slip detection device for gantry crane. Safety of special equipment in China, 03: 16-18. 